\title{
発泡スチロールの衝撃による圧縮応力ーひずみ特性*
}

\author{
二川曉美** 山崎 真 治***
}

\section{Dynamic Stress-Strain Properties of Styrofoams}

by

\author{
Akemi Futakawa and Shinji Yamasaki \\ (Mitsubishi Electric Corporation, Central Research Laboratory, Amagasaki)
}

This paper presents the dynamic stress-strain properties of styrofoams. Two ballistic pendulums were used in this experiment. The specimens, which had been bonded on the end surface of the pendulum being impacted, were loaded by the impact pendulum. The accelerationtime curves induced in the impacted pendulum were measured. The dynamic stress and strain were calculated by integrating these acceleration-time curves numerically. The effects of the strain rates and the number of impact loadings on the dynamic properties of styrofoams were examined and the accuracy of the test result was also discussed. The results obtained are as follows :

(1) The dynamic stress-strain properties of foamed plastics can be obtained with the accuracy of about 3 percent by this experimental method.

(2) The strength and stiffness of styrofoams increase with increasing the strain rate up to about $20 / \mathrm{sec}$, beyond which they start to decrease.

(3) The stiffness of styrofoams is remarkably reduced by the first application of impact loading but does not change any more by its further successive applications.

(4) At the strain rate of about $35 \sim 40 / \mathrm{sec}$, styrofoams disintegrate in an explosive manner. Therefore, the styrofoams seem to have the critical deformation rate in the vicinity of this strain rate.

(Received May 1, 1972)

\section{1 緒}

言

プラスチック発泡体は機器や部材を振動や衝撃から 絶縁する包装緩衝材料として広く用いられている。プ ラスチック発泡体に衝撃荷重が作用した場合，それは 非常に複雑な変形挙動を示し, またその応力やひずみ の外力汶対する力学的応答も入力条件の相違によって かなり異なった様相を示す。したがって，プラスチッ ク発泡体の衝撃荷重に対する動的特性を明らかにする ことは，材料の基礎的特性を解明する観点で，また実 用的には包装緩衝設計の観点で, 種々の興味深い問題 を含んでいる。

プラスチック発泡体の動的特性に関する研究は比較 的少なく, わずかに S. J. Green らのの゚リウレタンフ ォームの高速変形挙動に関する報告が散見されるにす ぎない，とくに通常包装緩衝材料として広く用いられ ている発泡スチロールの動的特性に関する報告はほと んぞないようである。

本研究では, 上記の観点から, 発泡スチロールに衝

* 原稿受理 昭和 47 年 5 月 1 日

** 正会員 三菱電機(株)中央研究所 尼崎市南清水字中野

*** 三菱電機(粎)中央研究所 尼崎市南清水字中野
撃荷重が作用した場合の動的圧縮応力ーひずみ特性を は握することを試みた。本稿では，まず二つの弾道形 振子を用いた衝撃試験法の原理㧍よび圧縮応力とひず 又の解析法について述べる.つぎに試料を端面に取り 付けた被衝撃振子に生じる加速度变化の測定結果, 牱 よびこれょり動的圧縮応力ーひずみ特性を解析し，こ の動的特性に抢よ汭すひずみ速度や負荷の繰返し回数 の影響について検討した結果を述べる。最後に本実験 の精度について検討した結果を述べる。

\section{2 実験方法 2 (2) 原理}

本研究では，E. Volterra らが報告している二つの 弾道形振子による衝撃試験法を用いた。そこで以下に 本実験法の原理特よび動的圧縮応力とひずみの解析法 について述べる。

Fig. 1 (a)は静止した被衝撃振子の端面に取り付けた

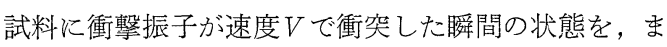
たFig. 1 (b)はその後時間 $t$ を経過したときの両振子の 位置をとれぞれ示したものである。本稿では，Fig. 1 に示すように, 試料衝撃荷重を与える振子を衝撃振 子, また試料を端面に取り付けて衝撃荷重を受ける振 子を被衝撃振子と呼ぶことにする。Fig. 1亿示すよう 
(a)

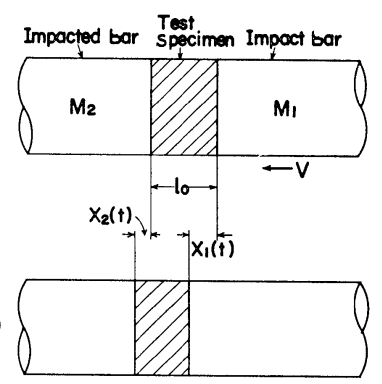

Fig. 1. Deformation of test specimen during interval of impact loading.

に, 衝撃振子の質量を $M_{1}$, 被衝撃振子の質量を $M_{2}$ とし、また衝撃荷重を試料に負荷してから任意の時間 $t$ が経過したときの両振子の位置を, Fig. 1(a)沉示す 両振子の位置を基準として, 運動方向に沿って測った 距離 $X_{1}(t), X_{2}(t)$ で表わす。 いま任意の時間 $t$ 亿抒 社る衝撃振子の被衝撃振子に対する相対的距離を $S(t)$ とすれば，これは

$$
S(t)=X_{1}(t)-X_{2}(t)
$$

で表わされる。

したがって, 衝撃荷重の負荷前後に怙ける二つの振 子の運動量保存関係と(1)式より, 任意の時間 $t$ 飞括仔 る試料の変形の加速度は

$$
\frac{d^{2} S(t)}{d t^{2}}=-\frac{M_{1}+M_{2}}{M_{1}} \frac{d^{2} X_{2}(t)}{d t^{2}}
$$

で表わすことができる。

この結果から, 被衝撃振子の加速度変化を実験的に 求め, $S(0)=0, d S(0) / d t=V$ の初期条件のもとで, 測定した加速度变化を用いて(2)式を 2 回数值積分すれ ば, 試料の変形量 $S(t)$ が求まることがわかる.

つぎに，動的圧縮応力とひずみの解析法について述 べる. 試料の変形量 $S(t)$ が求まると, 任意の時間 $t$ そお污るひずみ $\varepsilon(t)$ は

$$
\varepsilon(t)=\frac{S(t)}{l_{0}}
$$

で求をる．ただし $l_{0}$ は試料のもとの厚さである.

またこの時点で試料に生じる動的圧縮応力 $\sigma(t)$ は

$$
\sigma(t)=\frac{M_{2}}{A}-\frac{d^{2}}{d X_{2}(t)}
$$

で求をる。ただし $A$ は試料の断面積である.

以上の手順で求めた任意の時間 $t$ 亿和将る動的圧縮 応力 $\sigma(t)$ とひずみ $\varepsilon(t)$ を対応させると, 動的圧縮応 カーひずみ曲線上の 1 点が定まる。したがって，この 操作を任意の各時間 $t$ 亿対して繰り返すと，1本の動 的圧縮応力ーひずみ曲線を求めることができる.

\section{3 実験装置と実験方法}

\section{$3 \cdot 1$ 供試試料}

供試材料は比重 0.013 , 厚さ $30 \mathrm{~mm}$ の発泡スチロ ール板で，これょり $50 \phi \mathrm{mm}$ の円板状の試料を切り出
した。本研究ではこれらの試料を以下に述べる静的掠 よび動的圧縮試験に供した。

\section{$3 \cdot 2$ 静的圧縮試験}

動的圧縮応力ーひずみ特性と静的なそれを比較する ために，0.001/sec の定ひずみ速度で圧縮試験を行な い，供試試料の静的圧縮応力ーひず多特性を調べた。

\section{$3 \cdot 3$ 動的圧縮試験}

$3 \cdot 3 \cdot 1$ 実験装置 本研究に用いた実験装置の概 略をFig. 2 亿示す．Fig. 2 亿示すように，本実験装置 の本体は水平沉吊した二つの弾道形振子で構成した。 両振子の直径は試料と同じ $50{ }^{\circ} \mathrm{mm}$ とし，その長さは 試料最高 $80 \%$ の圧縮ひずみを生ぜしめることができ るように $1 \mathrm{~m}$ とした。

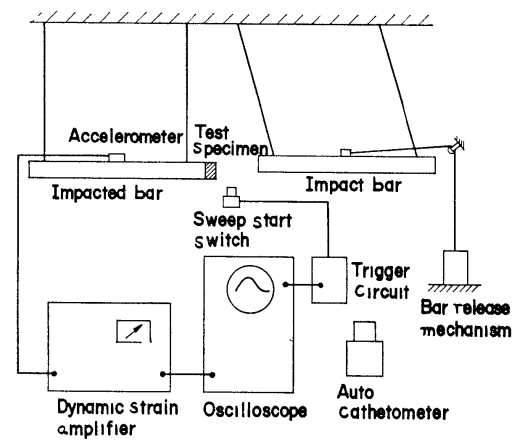

Fig. 2. Schematic diagram of experimental equipment.

溳定装置は被衝撃振子の中央部に取り付敄た抵抗線 ひずみ計形加速度計, 動ひずみ計, ブラウン管オシロ グラフおよびトリガ回路で構成した。加速度計には測 定する加速度変化の周波数の 10 倍以上の 固有振動数 $(375 \mathrm{~Hz})$ を有するるのを選定した。トリカ回路は近 接スイッチおよびリレー回路で構成し，衝撃振子が試 料衝突する直前に近接スイッチより信号を取り出し て、ブラウン管オシログラフを単掃引させた。

$3 \cdot 3 \cdot 2$ 実験方法 Table I 飞本実験で選定した 衝撃振子の落下高さを示す。 また同表には衝撃振子が 試料衝突する速度 $V$, 抢よびこの速度を試料の厚さ $l_{0}$ で除して得られる初ひずみ速度 $\varepsilon_{0}$ も併記した。な 牤本実験では衝突速度 $V$ は直接測定しなかった。これ

Table I. Test conditions.

\begin{tabular}{c|c|c}
\hline $\begin{array}{c}\text { Predetermined hight } \\
h(\mathrm{~cm})\end{array}$ & $\begin{array}{c}\text { Impact velocity } \\
V(\mathrm{~cm} / \mathrm{sec})\end{array}$ & $\begin{array}{c}\text { Int1al strain rate } \\
\dot{\varepsilon}_{0}(1 / \mathrm{sec})\end{array}$ \\
\hline 15 & 542 & 181 \\
30 & 76.7 & 25.6 \\
4.5 & 939 & 31.3 \\
60 & 1090 & 361 \\
\hline
\end{tabular}


は尒備実験で速度測定を行なった結果, Table I に示 す衝撃振子の落下高さをFig. 2 に示すオートカセトメ ータで $\pm 0.01 \mathrm{~mm}$ の精度範囲に設定すると， $V=$ $\sqrt{2 g h}$ ( $g$ は重力の加速度) で求まる速度と約 $1 \%$ の 精度範团で一致し，再現性も良好であったことによる ものである。

実験では，まず衝撃振子を Table I に示す落下高 さに設定し，つぎに発射装置により衝撃振子を自由落 下させて, 静止した被衝撃振子の端面に取り付けた試 料に衝撃荷重を負荷し，このとき被衝撃振子に生じる 加速度変化をブラウン管オンログラフで記録した。ま た衝撃荷重が繰返し作用した場合の動的圧縮応力ーひ ずみ特性の変化の状沉を調べるために，衝撃振子の落 下高さを $3.0 \mathrm{~cm}$ に保って同一試料に衝撃荷重を 2 3 回繰返し作用させて同様の実験を行なった。

\section{4 実 験 結 果}

Fig. 3(a)，(b)に初ひずみ速度が $\dot{\varepsilon}_{0}=18.1 / \mathrm{sec}$ と $\dot{\varepsilon}_{0}$ $=25.6 / \mathrm{sec}$ の場合の，またFig. 4 (a)，(b)に初ひずみ 速度を $\dot{\varepsilon}_{0}=25.6 / \mathrm{sec}$ に保って同一試料に衝撃荷重を 2 回ないし 3 回負荷した場合の被衝撃振子の加速度变 化を測定した結果の一例を示す。

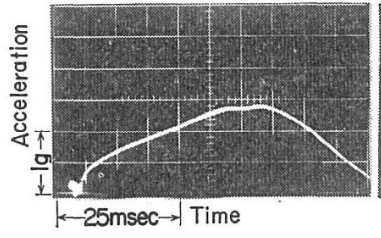

(a) $\dot{\varepsilon}_{0}=18.1 / \mathrm{sec}$

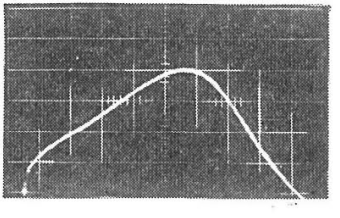

(b) $\dot{\varepsilon}_{0}=25.6 / \mathrm{sec}$
Fig. 3. Acceleration-time curves induced in impacted pendulum on initial strain rates.

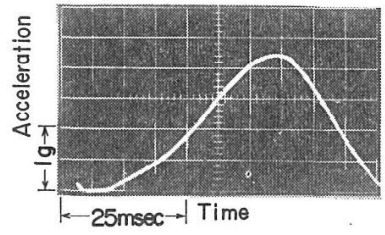

(a) Second time

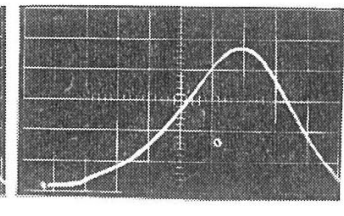

(b) Third time
Fig. 4. Acceleration-time curves induced in impacted pendulum on number of impact loading with 25.6/ sec strain rate.

Fig. 3(a)，(b)より，被衝撃振子に生じる加速度の最 大值は初ひずみ速度の増加ととるに增大することがわ かる、をた同一試料に同一初ひずみ速度で 2 回衝撃荷 重を負荷した場合には，Fig. 3 (b) と Fig. 4 (a)を比較す れば明らかなよらに, 被衝撃振子に生じる加速度変化 の立ら上りは著しく低下し, また加速度の最大值は若 干増大する傾向がみられる。乙かし, さらに同一条件 で 3 回衝撃荷重る作用させた場合には，Fig. 4 (a)，(b) から明らかなよらに, 被衝撃振子に生じる加速度変化
は2 回目のそれとそれ活ど大きな差異を生じないこと がわかる。

\section{5 検討}

\section{$5 \cdot 1$ 動的圧縮応力ーひずみ特性の性質}

Fig. 5 とFig. 6 は, 被衝撃振子に生じる加速度变化 の測定結果执よび(2)〜(4)式より求めた動的圧縮応力一 ひずみ曲線である．以下にこの結果にもとついて動的 圧縮応力ーひずみ特性の性質について検討する。

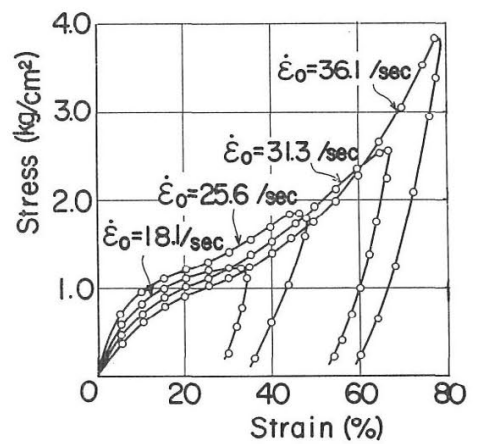

Fig. 5. Stress-strain diagrams on initial strain rates.

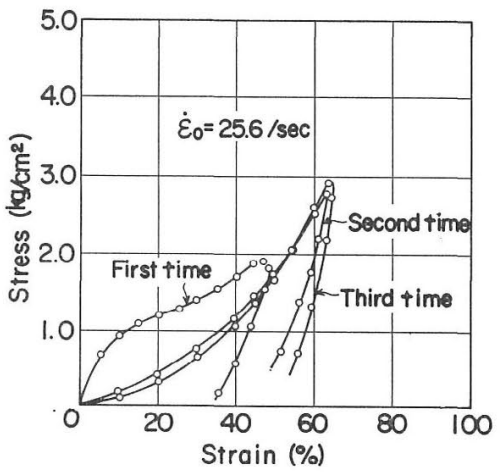

Fig. 6. Stress-strain diagrams on repeated impact loadings.

$5 \cdot 1 \cdot 1$ 初ひずみ速度の影響 Fig. 5 は初ひずみ 速度が $\dot{\varepsilon}_{0}=18.1 / \mathrm{sec}$ から $\dot{\varepsilon}_{0}=36.1 / \mathrm{sec}$ の範囲で求 めた動的圧縮応力ーひずみ曲線である。初ひずみ速度 が $\dot{\varepsilon}_{0}=25.6 / \mathrm{sec}$ までの範囲では，初ひずみ速度の増 加ととるに動的圧縮応力ーひずみ曲線の立ら上りは増 大する。しかし，初ひずみ速度が $\dot{\varepsilon}_{0}=31.3 / \mathrm{sec}$ 以上 では, 初ひずみ速度が増加すると逆に動的圧縮応力一 ひずみ曲線の立ら上りは低下寸る傾向がみられる。

$5 \cdot 1 \cdot 2$ 衝撃荷重の負荷回数の影響 Fig. 6 は初 ひず久速度を $\dot{\varepsilon}_{0}=25.6 / \mathrm{sec} に$ 保って，同一試料に衝 撃荷重を 1 〜 回負荷した場合の動的圧縮応力ーひず み曲線である。衝撃荷重を 1 度作用させると試料に永 久ひずみが生じるが，衝撃荷重の繰返し作用によって 動的特性の変化する様子をは握し易くするために，同 
図では㧍の括のの衝撃荷重の負荷時点を基準にしてい ずれも原点をそろ㢳理した。

衝撃荷重を 1 度負荷すると, 発泡スチロールを構成 するセルに座屈や破壊が生じるため，Fig. 6 にみられ るように, 衝撃荷重を2 回負荷した場合の動的圧縮応 力ーひずみ曲線の立ち上りは 1 回目のそれに比較して 著しく低下し，また試料に生じる圧縮応力およびひず みの最大值は増大する. しかし, 衝撃荷重の負荷回数 が 3 回目の動的圧縮応力ーひずみ曲線 は衝撃荷重を 2 回負荷した場合のそれとほとんど差異がみられないの で,この結果から 3 回目の衝撃荷重の負荷に伴って発 泡スチロールを構成しているセルの座屈や破壊がそれ ほど進行していないことがわかる。

$5 \cdot 1 \cdot 3$ 静的特性と動的特性の比較 Fig. 5 の動 的圧縮応力ーひずみ曲線は，ひずみ速度が变化する状 態で求めたものである。そこでつぎに静的特性と動的 特性を比較するために, 定ひずみ速度での動的圧縮応 力ーひずみ曲線を求めることを試みる.

衝撃後任意の時間 $t$ に括汀る試料の変形速度は, (2) 式を 1 回数值積分すると求まるので，このときのひず 夕速度 $\varepsilon(t)$ は

$$
\varepsilon(t)=\frac{1}{l_{0}} \frac{d S(t)}{d t}
$$

で求まる.

したがって，任意の時間 $t$ に和ける動的圧縮応力 $\sigma(t)$ とひずみ速度 $\dot{\varepsilon}(t)$ を対応させると, 動的圧縮応 力ーひずみ速度曲線上の 1 点が定まる. この操作を各 時間 $t$ に対して繰返すと，Fig. 7 に破線で示す動的圧 縮応力ーひずみ速度曲線を得る．Fig. 7 の 1 本の破線 は Fig. 5 の 1 本の動的圧縮応力ーひずみ曲線と対応し ている.この曲線上にひずみが $10 〜 60 \%$ 範囲で $10 \%$ ごとに等ひずみ曲線を求めると Fig. 7 の実線のように なる. Fig. 7 より定ひずみ速度での動的圧縮応力ーひ ずみ曲線を求めた結果をFig. 8 に示す. Fig. 8 には $0.001 / \mathrm{sec}$ の定ひずみ速度での静的圧縮応力-ひずみ

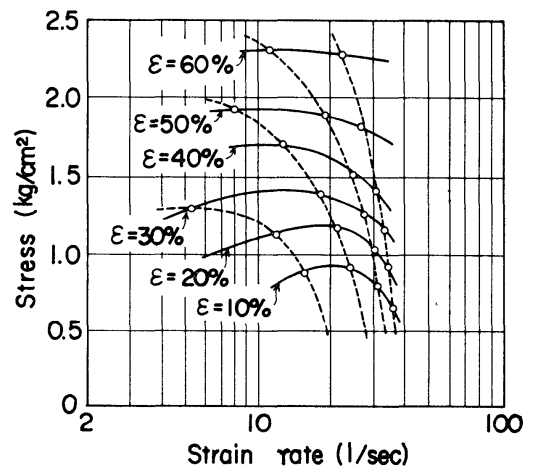

Fig. 7. Relationship between stress and strain rate.

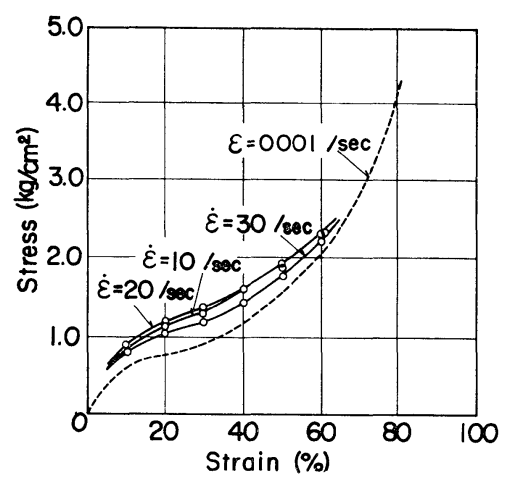

F1g 8. Stress-strain diagrams on strain rates.

曲線も破線で併記した。

Fig. 8 で静的特性と動的特性を比較すると，ひずみ が10〜60\%の範囲では，同一ひずみに対して動的圧縮 応力は静的圧縮応力の約 1.2〜1.6 倍になっているこ とがわかる。またひずみ速度が $\dot{\varepsilon}=10 / \mathrm{sec}$ と $\varepsilon=20 /$ sec に対する動的圧縮応力ーひずみ曲線 はほとんど差

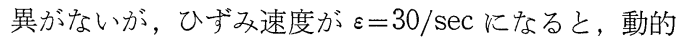
圧縮応力ーひずみ曲線の立ち上りは若干低下する傾向 がみられる。

$5 \cdot 1 \cdot 4$ 限界のひずみ速度，つぎに発泡スチロー ルの変形に及ぼすひずみ速度の影響について検討する ことを試みる。

Fig. 9 は圧縮応力をパラメータとしてFig. 7 をひず み速度とひずみの関係で書き直した結果である．Fig. 9 よりひずみ速度が 35〜 40/sec 付近で発泡スチロー ルの変形が急激に増大することがわかる。このひずみ 速度で試料に衝撃荷重が作用すると, 試料は一様に変 形せず，破裂音を伴って飛散して破壞する現象がみら れる。この結果から，このひずみ速度付近に供試発泡 スチロールの限界のひずみ速度が存在し，このひずみ 速度以上では供試発泡スチロールは緩衝材料として実 用に供し得ないと考えられる。

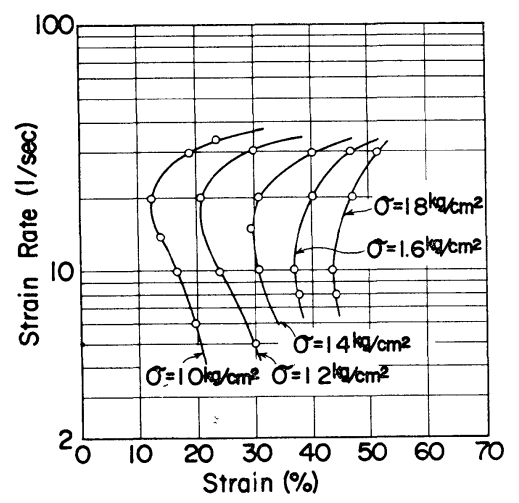

Fig. 9. Relationship between strain rate and strain. 


\section{$5 \cdot 2$ 動的圧縮応力ーひずみ曲線の精度}

本検討で求めた動的圧縮応力ーひずみ曲線 の精度を エネルギ保存則の観点から検討することを試みる。

動的圧縮応力ーひずみ曲線とひずみ軸の間に囲まれ る部分の面積は, 試料の単位体積当たりの衝撃吸収工 ネルギを表わすので, まずこの部分の面積を数值積分 で求め, 任意の時間 $t$ まで䚶試料全体が吸収したエネ ルギ $Q_{1}$, を求め, またこの時間 $t$ 亿执いて衝撃振子と 被衝撃振子の有する運動エネルギの和 $Q_{2}$ を求める.

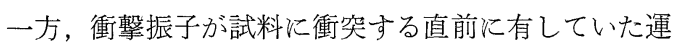
動エネルギ $Q_{0}$ を求める. Table II は $\dot{\varepsilon}_{0}=25.6 / \mathrm{sec}$ の場合を例飞, 以上の手順により $\left(Q_{1}+Q_{2}-Q_{0}\right) / Q_{0}$ を 求めた結果である. Table II より各時間 $t$ について この值は約 $3 \%$ 以下の範囲にばらついていることがわ かる. したがって, 本実験で求めた動的圧縮応力ーひ ずみ曲線の精度は約 $3 \%$ 程度であると考它られる。こ の実験精度に大きな影響を及涪す因子としては，圧縮 応力とひずみの数值計算の過程で介入する作戝拈よび

Table II. Comparison of total energy during interval of impact loading with initial kinetic energy.

\begin{tabular}{c|c|c}
\hline $\begin{array}{c}\text { Time } \\
t(\mathrm{msec})\end{array}$ & $\begin{array}{c}\text { Total energy } Q_{1}+Q_{2} \\
(\mathrm{~kg} \mathrm{~cm})\end{array}$ & $\begin{array}{c}\frac{\left(Q_{1}+Q_{2}\right)-Q_{0}}{Q_{0}} \times 100 \\
(\%)\end{array}$ \\
\hline 0 & 1019 & - \\
4 & 1000 & 196 \\
8 & 1019 & 00 \\
12 & 103.3 & -127 \\
16 & 1011 & 088 \\
20 & 99.6 & 2.35 \\
24 & 1008 & 118 \\
28 & 1007 & 1.28 \\
\hline
\end{tabular}

プロットの読み取り誤差が考えられる。

$$
6 \text { 結論 }
$$

二つの弾道形振子を用いた衝撃試験法で, 発泡スチ ロールの動的圧縮応力ーひずみ特性を調べ，これにお よぼすひずみ速度や衝撃荷重の負荷回数の影響や本実 験の精度について検討した。本研究で得られた結果を 要約すればつぎのようになる。

(1) 本検討で適用した二つの弾道形振子による衝撃 試験法で, プラスチック発泡体の動的圧縮応力ーひず み特性を約 $3 \%$ の精度で求めることがでさる.

（2）供試発泡スチロールは $20 / \mathrm{sec}$ 以下のひずみ速 度範囲では, ひずみ速度の増加とともにその強度およ び剛性は増大する傾向がみられるが，それ以上のひず み速度範囲では逆にそれらは低下する。

（3）供試発泡スチロールに衝撃荷重を1度負荷する とその岡性は著しく低下するが，さらに同一試料に同 一エネルギの衝撃荷重を $2 \sim 3$ 回繰返して作用させた 場合にはその剛性は注とんど变化しない.

（4）35 40/sec 付近のひずみ速度で衝撃荷重を負 荷すると, 供試発泡スチロールは急激な変形を伴って 破壊し，このひずみ速度付近に実用的な限界のひずみ 速度が存在すると考えられる。

（昭和 42 年 9 月 8 日 第 11 回材料研究連合講演会にて講演）

\section{参 考 文 献}

1) Green, S. J., F. L. Schierloh, R. D. Perkins, and S G Babcock, Experımental Mechanics, 9, 3, 103 (1969).

2) Volterra, E., R. A. Eubanks, and D. Muster, SESA Proceedings, 13, 1, 85 (1955).

3) Volterra, E., and C.S. Barton, SESA Proceedings, 16, 1, 157 (1958). 